\title{
The Effect of Progressive Muscle Relaxation and Slow Deep Breathing Toward Vital Signs of Patients' Hypertension in The Working Area of Bengkuring Medical Center (Puskesmas)
}

\author{
Ismansyah, Ismansyah*, Parellangi , Andi, Firdaus, Rivan, and Wiadiastuti, and \\ Hesti Prawita \\ 1Poltekkes Kemenkes Kalimantan Timur, Jl. W. Monginsidi No.38, Sidodadi, Samarinda Ulu, Kota Samarinda, \\ Kalimantan Timur 75243, Indonesia \\ *Correspondence: isman_rafky@yahoo.co.id \\ Type of the Paper (Article)
}

Received: May 6, 2019; Accepted: June 26, 2019; Published: September 01, 2019

https://doi.org/10.29253/achnr.2019.13320

\begin{abstract}
This study aims to determine the effect of progressive muscle relaxation and slow deep breathing toward the vital signs of hypertensive patients. Using the quasi experiment with pre and posttest without control. The sample size 22 respondent, of each group of 11 people was conducted 7 times intervention, both with progressive muscle relaxation and slow deep breathing. The data collection was conducted using an observation form. The results of hypothesis testing with the Paired T-Test and Wilcoxon found that there was an effect of progressive muscle relaxation toward the vital signs, systolic blood pressure, diastolic, and pulse values obtained $\mathrm{p}=0.000$, while respiration 0.020 , body temperature 0.006 . Interventions with slow deep breathing obtained $\mathrm{p}$ value of systolic 0.011 , diastolic 0.001 , pulse 0.000 , respiration 0.012 , and body temperature 0.043 . Analysis of differences in the two groups with Independent T-Test obtained the value of systolic blood pressure $=0.001$, diastolic 0.066 , pulse 0.000 , respiration 0.011 , and body temperature 0.055 . In addition, it concludes the progressive muscle relaxation has an effect on systolic, diastolic, pulse, body temperature compared to slow deep breathing, but slow deep breathing intervention has more influence on respiration than progressive muscle relaxation.
\end{abstract}

Keywords: hypertensive; progressive muscle relaxation; slow deep breathing; vital signs

\section{Introduction}

Cardiovascular disorders consist of hypertension is one of the causes of death, which will increase to approximately 23.3 million deaths in 2030 . The latest statistical data states that there were $26.6 \%$ of Indonesia's population experiencing cardiovascular disease in 2015 (WHO, 2017). Lifestyle modification and relaxation techniques might control the blood pressure in patients with hypertension (Black J, and Hwaks, 2005).

Therefore, one of the non-pharmacological interventions includes the progressive muscle relaxation, which is simple relaxation by tensing and relaxing the muscles of the body. Previous research by Isnaini Herawati, 2016 showed progressive muscle relaxation had an effect on decreasing systolic blood pressure for patients with primary hypertension (Herawati \& Azizah, 2016). While slow deep 
breathing is a technique of doing deep breath, slow breathing, and exhaling slowly. The slow deep breathing is useful to reduce blood pressure because it might stimulate the appearance of nitric oxide which functions as a vasodilator (Setyaningrum, 2016). Effect of deep breathing techniques on blood pressure reduction in hypertensive at Bendosari Medical Center (PUSKESMAS) Sukoharjo (Hastuti, R T \& Insiyah, 2015).

This is the prominent comprehension of the author to further examine the effects of progressive muscle relaxation and slow deep breathing toward vital signs.

\section{Methods}

The design used is quasi experiment, namely pre and post-test without control group. The research respondents were divided into 2 treatment groups such as the progressive muscle relaxation treatment group and slow deep breathing. The sample size is determined by taking all member of population into samples according to the inclusion criteria is 22 respondents, then conducted a simple random sampling by using random number generator is research randomize program to determined group. There consist of two group, each group is 11 people. Data collection was conducted in the working area of Bengkuring Medical Center Samarinda, in April 2018 using an observation form. The data distribution is normal except respiration rate, analysis using Shapiro Wilk test. The data analysis in this studyi using paired sample-t test, wilcoxon and independent - $t$ test to determine the effect of progressive muscles relaxasation and slow deep breathing toward of vital sign of hypertensive patients between before and after intervention. The study was conducted by measuring a blood pressure, pulse, respiration, and body temperature before and after the progressive muscle relaxation and slow deep breathing performed at the intervals of 5 minutes after the intervention was given for 1-week ( 7 times) treatment in each group.

\section{Results}

Table 1 shows the descriptive values of respondents' characteristics, which include gender and age in group 1 and group 2, which most of the respondents were female about 9 people (81.8\%). The characteristics of respondents based on the age were mostly the aged between 56-65 years in group 1 , which was $54.5 \%$ and group 2 which was $45.5 \%$.

Table 1. The characteristics of respondents in group 1 (Progressive muscle relaxation) and in group 2 (Slow deep breathing).

\begin{tabular}{lllll}
\hline Characteristics & $\begin{array}{l}\text { Group 1 } \\
\text { N }\end{array}$ & $\mathbf{\%}$ & $\begin{array}{l}\text { Group 2 } \\
\text { N }\end{array}$ & $\mathbf{\%}$ \\
\hline Gender & & & & \\
Male & 2 & 18.2 & 2 & 18.2 \\
Female & 9 & 81.8 & 9 & 81.8 \\
Age (Year) & & & & \\
$36-45$ & 1 & 9.1 & 1 & 9.1 \\
$46-55$ & 2 & 18.2 & 3 & 27.3 \\
$56-65$ & 6 & 54.5 & 5 & 45.5 \\
$66-75$ & 2 & 18.2 & 2 & 18.2 \\
Total & 11 & $100 \%$ & 11 & $100 \%$ \\
Source of value: Primary analysis, 2018 & & &
\end{tabular}

Table 2 shows the mean difference test before and after the intervention in group 1 and group 2 , the results showed that in group 1 for systolic, diastolic, and pulse obtained $p$ value $=0.000<0.05$, respiration of $\mathrm{p}$ value $=0.020<0.05$, and body temperature of $\mathrm{p}$ value $=0.006<0.05$. In additional, it might be concluded that there is an effect of progressive muscle relaxation toward the vital signs in group 1. 
Table 2. The mean difference test before and after the intervention in group 1 (Progressive muscle relaxation) and group 2 (Slow deep breathing).

\begin{tabular}{|c|c|c|c|c|c|}
\hline Vital signs & $\mathbf{N}$ & $\begin{array}{l}\text { Mean } \pm \text { deviation } \\
\text { standard } \\
\text { Median(Min-Max) } \\
\text { Before } \\
\text { intervention } \\
\end{array}$ & $\begin{array}{l}\text { Mean } \pm \text { deviation } \\
\text { standard } \\
\text { Median (Min- } \\
\text { Max) } \\
\text { After intervention }\end{array}$ & Deviation & $\begin{array}{l}\text { P } \\
\text { Value* }\end{array}$ \\
\hline \multicolumn{6}{|c|}{ Group 1 (Progressive muscle relaxation) } \\
\hline Systolic & 11 & $163.64 \pm 12.127$ & $142.09 \pm 11.335$ & $21.55 \pm 6.861$ & 0.000 \\
\hline Diastolic & & $97 \pm 8.729$ & $90.64 \pm 7.632$ & $6.55 \pm 2.911$ & 0.000 \\
\hline Pulse & & $89.73 \pm 9.045$ & $74.82 \pm 6.954$ & $14.55 \pm 4.525$ & 0.000 \\
\hline Respiration & & $20.27 \pm 1.04$ & $19.45 \pm 1.293$ & $0.82 \pm 0.982$ & 0.020 \\
\hline $\begin{array}{l}\text { Body } \\
\text { temperature }\end{array}$ & & $36.418 \pm 0.1401$ & $36.191 \pm 0.2343$ & $0.227 \pm 0.2149$ & 0.006 \\
\hline \multicolumn{6}{|c|}{ Group 2 (Slow deep breathing) } \\
\hline Systolic* & 11 & $\begin{array}{l}165 \\
(140-200)\end{array}$ & $\begin{array}{l}155 \\
(140-192)\end{array}$ & $\begin{array}{l}8 \\
(-2-21)\end{array}$ & 0.011 \\
\hline Diastolic & & $90 \pm 14.677$ & $85.64 \pm 12.667$ & $3.91 \pm 3.419$ & 0.001 \\
\hline Pulse & & $86.09 \pm 6.316$ & $81.91 \pm 7.674$ & $4.18 \pm 2.523$ & 0.000 \\
\hline Respiration* & & $\begin{array}{l}19 \\
(17-21)\end{array}$ & $\begin{array}{l}17 \\
(16-20)\end{array}$ & $\begin{array}{l}2 \\
(0-4)\end{array}$ & 0.012 \\
\hline $\begin{array}{l}\text { Body } \\
\text { temperature }\end{array}$ & & $36.373 \pm 0.2102$ & $36.282 \pm 0.1401$ & $0.064 \pm 0.1567$ & 0.043 \\
\hline
\end{tabular}

Description table: ${ }^{*}=$ Tested by using the Wilcoxon because the value is not normally distributed consequently the value taken is the median, minimum, and maximum values.

Based on table 3 , there are different mean tests of vital signs after intervention in group 1 and group 2. For systolic of $p$ value $=0.026<0.05$, pulse of $p$ value $=0.034<0.05$ and respiration value $=0.003<0.05$ using Mann test Whitney-U, this means that after intervention in both groups there were significant differences. However, in the diastolic obtained value $=0.275>0.05$ and body temperature of $p$ value $=$ $0.283>0.05$ with the independent $t$-test, this means that after intervention in both groups there was no significant difference.

Table 3. The differential test on average change of vital signs after the intervention in group 1 (Progressive muscle relaxation) and group 2 (Slow deep breathing).

\begin{tabular}{|c|c|c|c|c|}
\hline Vital signs & & $\mathbf{N}$ & $\begin{array}{l}\text { Mean } \pm D S \\
\text { Median (Min-Max) }\end{array}$ & P Value* \\
\hline Systolic* & Group 1 & 11 & 139 (122-161) & 0.026 \\
\hline Diastolic & $\begin{array}{l}\text { Group } 1 \\
\text { Group } 2\end{array}$ & & $\begin{array}{l}90.64 \pm 7.632 \\
85.64 \pm 12.667\end{array}$ & 0.275 \\
\hline Pulse & $\begin{array}{l}\text { Group } 1 \\
\text { Group } 2\end{array}$ & & $\begin{array}{l}74.27 \pm 6.278 \\
81.91 \pm 7.674\end{array}$ & 0.034 \\
\hline Respiration* & $\begin{array}{l}\text { Group } 1 \\
\text { Group } 2\end{array}$ & & $\begin{array}{l}19(18-22) \\
17(16-20)\end{array}$ & 0.003 \\
\hline $\begin{array}{l}\text { Body } \\
\text { temperature }\end{array}$ & $\begin{array}{l}\text { Group } 1 \\
\text { Group } 2 \\
\end{array}$ & & $\begin{array}{l}36.191 \pm 0.2343 \\
36.282 \pm 0.1401 \\
\end{array}$ & 0.283 \\
\hline
\end{tabular}

Description: *= Tested by using Mann Whitney because the value is not normally distributed consequently the value taken is the median, minimum, and maximum values.

In table 4, the average difference test of the vital signs in group 1 and group 2 was tested by using the independent T-test because all data were normally distributed and homogeneously. For the systolic 
difference of $p$ value $=0.001<0.05$, the difference of $p$ value $=0.000<0.05$, respiration difference of $p$ value $0.011<0.05$ means that the value of systolic difference, pulse and respiration in the two groups had significant differences. While the diastolic difference obtained of $p$ value $=0.066>0.05$ and the difference in body temperature of $p$ value $=0.055>0.05$ this means that the value of the difference in the two groups there is no significant difference.

Table 4. The mean difference test in changes of vital signs in group 1 (Progressive muscle relaxation) and group 2 (Slow deep breathing).

\begin{tabular}{|c|c|c|c|c|}
\hline \multicolumn{2}{|c|}{ Vital signs } & $\mathbf{N}$ & Mean deviation $\pm \mathrm{DS}$ & $\mathbf{P}$ \\
\hline \multirow[t]{2}{*}{ Systolic } & Group 1 & 11 & $21.55 \pm 6,861$ & 0.001 \\
\hline & Group 2 & & $8.91 \pm 8.360$ & \\
\hline \multirow[t]{2}{*}{ Diastolic } & Group 1 & & $6.55 \pm 2.911$ & 0.066 \\
\hline & Group 2 & & $3.91 \pm 3.419$ & \\
\hline \multirow[t]{2}{*}{ Pulse } & Group 1 & & $14.55 \pm 4.525$ & 0.000 \\
\hline & Group 2 & & $4.18 \pm 2.523$ & \\
\hline \multirow[t]{2}{*}{ Respiration } & Group 1 & & $0.82 \pm 0.982$ & 0.011 \\
\hline & Group 2 & & $2.09 \pm 1.136$ & \\
\hline \multirow[t]{2}{*}{ Body temperature } & Group 1 & & $0.227 \pm 0.2149$ & 0.055 \\
\hline & Group 2 & & $0.064 \pm 0.1567$ & \\
\hline
\end{tabular}

\section{Discussion}

The results showed that there was a significant effect between the progressive muscle relaxation and systolic, diastolic, pulse, respiration, and body temperature. Likewise, there is a significant influence between the slow deep breathing and the levels of systolic, diastolic, pulse, respiration, and body temperature. The results of this study are in line with those conducted which states that progressive muscle relaxation affects the decrease in systolic blood pressure for patients with primary hypertension (Herawati \& Azizah, 2016). Despite that it might be concluded that progressive muscle relaxation is a method to help reduce strain accordingly that the body muscles relax, according to the opinion of Ramdhani \& Putra (2009). Likewise, the decreasing of vital signs might occur because when doing progressive muscle relaxation, calm, relaxed, and full of concentration (deep relaxation) towards tension and relaxation of muscles trained for 10-30 minutes as the results of the secretion of CRH (corticotrophin releasing hormone) and ACTH (adrenocorticotropic hormone) in the hypothalamus downhill. The second decrease in the secretion of this hormone causes the sympathetic nerve activity to decrease. Likewise, the release of adrenaline and noradrenaline decreases, as a result, there is a decrease in heart rate, dilated blood vessels, decreased vascular resistance, and a decrease in heart pump as the result of the heart arterial blood pressure decreases (Sherwood, 2011).

However, in the group which was given the slow deep breathing intervention showed almost the same results as the group, which was given the intervention of progressive muscle relaxation. The results of this study were supported by previous research conducted by Hartanti in Pekalongan in 2016 showed that there is an effect of deep breathing-relaxation therapy on decreases in systolic and diastolic blood pressure in hypertensive patients in Pekalongan, Kesesi Village (Hartanti \& Wardana, 2016).

Furthermore, the slow deep breathing is an action that is consciously done to regulate breathing deeply and slowly. Deep breathing is to reduce the frequency of breathing 16-19 times in one minute to 6-10 times in one minute. Deep breathing will stimulate the appearance of oxygen and nitrites, which will enter the lungs even to the brain, increasing the release of nitric oxide, which then causes the blood vessels to relax, elastic and dilate, decrease heart rate, and heart contraction. Relaxing the blood vessels will widen as the result the blood circulation becomes smooth, the central venous pressure (CVP) decreases, and the heart's work becomes optimal.

The reduction in blood pressure after the treatment of the progressive muscle relaxation intervention is greater than the decrease in blood pressure after treatment of slow deep breathing intervention because progressive muscle relaxation therapy for individuals will be given the opportunity to learn how to strain certain groups of muscles then release the tension. When you feel both, the respondent begins to distinguish sensations when the body's muscles are tense and relaxed (Ramdhani \& Putra, 2009). Despite that slow intervention deep breathing only focuses on breathing as the result the 
body's system coverage becomes relaxed only slightly, while the intervention of progressive muscle relaxation might relax almost all of the body's muscles. However, based on the results of the research conducted, it was concluded that there was a significant difference between the provision of progressive muscle relaxation and slow deep breathing interventions on systolic, pulse, and respiration, whereas there was no significant difference in diastolic and body temperature. In addition, if it is seen from the average value of the decline in vital signs (systolic, diastolic, pulse, and body temperature), it appears that the progressive muscle relaxation intervention has a greater effect on systolic, diastolic, pulse, and body temperature compared to slow deep breathing intervention, but on respiration the slow deep breathing intervention has more impact than progressive muscle relaxation intervention.

\section{Conclusions}

There is the influence of progressive muscle relaxation and slow deep breathing on systolic ( $\mathrm{p}$ value $=0.000)$, diastolic $(\mathrm{p}$ value $=0.000)$, pulse $(\mathrm{p}$ value $=0.000)$, respiration $(\mathrm{p}$ value $=0.020)$, and body temperature ( $\mathrm{p}$ value $=0.006)$

There is the effect of Slow Deep Breathing on systolic ( $p$ value $=0.011)$, diastolic $(\mathrm{p}$ value $=0.001)$, pulse $(p$ value $=0.000)$, respiration $(p$ value $=0.012)$, and body temperature $(p$ value $=0.043)$.

Conflicts of Interest: there is no conflict of interest.

\section{References}

Black J, and Hwaks, J. (2005). Medical Surgical Nursing: Clinical Management of Expected Results. (The 7th edition).

Hartanti, R. D., Wardana, D. P., \& Fajar, R. A. (2016). Breathing Relaxation Therapy in Reducing Blood Pressure in Hypertensive Patients, IX (1). http://www.journal.stikesmuh-pkj.ac.id> Vol 9, No 1 (2016)> Hartanti accessed on 12 October 2017.

Hastuti, Rini Tri \& Insiyah (2015). Penurunan Tekanan Darah Dengan Menggunakan Tehnik Nafas Dalam (Deep Breathing) Pada Pasien Hipertensi Di Puskesmas Bendosari Kabupaten Sukoharjo. Jurnal Ilmu Kesehatan : Interest. 4 (2), 130-135.

Herawati, Isnaini \& Azizah, Siti Nur (2016). Effect Of Progressive Muscle Relaxation Exercise To Decrease Blood Pressure For, 405-412.

Ramdhani, \& Putra. (2009). Development of Multimedia Relaxation. Journal Psychology, 34 No. 2.

Setyaningrum, N. (2016). Effectiveness of Progressive Muscle Relaxation and Slow Deep Breathing Toward Decreased Blood Pressure, Improved Sleep Quality and Decreased Stress Levels in Hypertension Patients in the Gamping 2 in working area of Medical Center Yogyakarta. 11(2), 89-101.

Sherwood. (2011). Human Physiology: From Cell to System (2nd Edition) Jakarta: EGC.

World Health Organization. (2017). World Health Statistics 2017 : Monitoring Health for The SDGs. World Health Organization. https://doi.org/10.1017/CB09781107415324.004 accessed on 21 October 2017. 